\title{
Trends of E-government in Czech Municipal and Regional Self -Government
}

\section{David Špaček ${ }^{1}$}

\begin{abstract}
The paper summarizes trends of e-government projects of Czech territorial self-governments (municipalities and regions). The summary is based on secondary data related to philosophy and practice of projects which were awarded or medialized as top projects in three Czech national e-government awards in the period 2005-2010.
\end{abstract}

Key words: e-government, e-governance, e-services, Czech e-government awards, selfgovernment

JEL Classification: H79

\section{Introduction}

E-Government represents one field where the mentioned values have been emphasized repeatedly in the last decade. We will not discuss various approaches to the content of the term in depth here. It is still apparent what Grand and Chau stated in 2005: definitions of e-government abound in the literature, we may add that the term is more stable particularly in its frequency (i.e. we do not meet terms like "digital government" or "on-line government" today as often as we did in the past, use of the term egovernment/e-governance is rather globalized), rather than in its content (i.e. definitions may still vary in their specifics across approaches). Current terminology may also emphasize a technology that is / is to be used - for example, it is the case of mgovernment that is currently extensively discussed (see e.g. Snellen and Thaens, 2008) or e-government 2.0 (see e.g. Criado, 2009, or Accenture, 2009). Still we may outline that the terms like e-government and e-governance usually refer to initiatives of governments from various levels that build on possibilities of electronic forms to serve as an alternative instrument for practical achieving of improvements (better outcomes) of governments, their bureaucracies and their decision- and policy-making processes in many ways - e.g. by simplification, speeding up, reduction of costs, enhancement of inclusion in public decision-making, control empowerment, making necessary administrative interactions and burdens more comfortable etc. Such improvements always relate to 2 groups of activities / interactions: to those which are / are to be under way:

a) in the public administration system itself (within an individual authority or in interrelationships among multiple public authorities); and / or

\footnotetext{
${ }^{1}$ Masaryk University, Faculty of Economics and Administration, Lipová 41a, 60200 Brno, Czech Republic, e-mail: david.spacek@econ.muni.cz.
} 
b) in external relationships between public (citizens, businesses, non-governmental organizations etc.) and more or less integrated back-offices of a single administrative authority or various public administration sub-systems. Here in particular are the edemocracy or even e-participation elaborated separately sometimes as a set of instruments attempting to improve government by achieving better governance (e.g. Macintosh and Whyte, 2006; Scherer, Schneider \& Wimmer, 2008; Špaček, 2008 and 2009).

If we compare terminology (see e.g. Špaček, 2010), we may say that regardless of the used terms, the terminology available always refers to a general notion of public administration as a service to citizens. The goal is to ensure that the practice of this principle will be based on / supported by new technologies. E-government also usually represents an alternative instrument which offers new means / methods of work for those who can and/or want to use them (although it is apparent that more duties are prescribed for public administration and businesses rather than for citizens).

In order to bring innovations, we may distinguish following trends (for example) in egovernment policies, legislation and projects of EU member states (Špaček, 2012, on the basis of epractice.eu factsheets, as well as on OECD, 2007, 2008 and 2009):

- establishment of new / revision of existing national portals that sometimes innovate their service delivery mechanisms (e.g. by using mobile IDs, by enhanced possibilities of personalization) or focus on a specific field of communication between government and businesses / citizens (including projects from the areas like e-procurement, e-invoicing, e-health, e-justice, e-environment and others)

- piloting e-participation and e-democracy projects (including the community building projects),

- promotion of more internationally recognized instruments for electronic identification (eIDs),

- searching for instruments enhancing effectiveness and efficiency inside public administration (e.g. promotion of open standards and software solution, more complex managerial information systems, as well as new institutional arrangements for e-government coordination and evaluation etc.).

So far, the criticism of e-government practice has argued that new technologies are insufficiently managed (and evaluated) and used in reorganizing the public administration, or that they do not involve the general public in decision-making regarding public affairs (see e.g. OECD, 2003 and 2009).

E-government ideas have been reflected in many realized or planned projects in Czech public sector, including the legislation as well as national or regional / local projects. In the Czech Republic, territorial public administration consists particularly of administration on the municipal and regional self-governments. The aim of the paper is to outline the specifics of e-government projects of Czech territorial self-government, and particularly summarize trends of e-government development in Czech territorial self-government. The paper attempts are based particularly on secondary data (publicly available information) which outlines the philosophy and practice of projects that have been awarded or presented among top 10 projects in three famous Czech e-government awards. Firstly, categories and sub-categories of projects (e-gov services) were created 
using the data about all the surveyed national competitions. Secondly, the projects of individual competitions were categorized in order to enable a comparison.

\section{E-government projects of territorial self-government in Czech national context}

In e-government projects of Czech territorial self-government (municipalities and regions), logically, their self-governmental status is reflected, which brings more autonomy for their decision-making, more space for flexibility which is limited by capacities of individual self-governments and by standardization requirements of legislation with regard to duties inside public administration, as well as in external relations with citizens. The standardization initiatives are important because the Czech Republic is specific for having a large number of municipalities. Currently, there are more than 6200 municipalities, most of which (almost 80\%) have less than 1000 inhabitants. This has raised questions and brought requirements for new legislation which - particularly since the new millennium - stipulates standardization initiatives on e-government development on the municipal level. Among important standardization instruments particularly the following legal documents are substantial (Špaček and Malý, 2010):

For the purposes of public e-services and their management, particularly the following existing legislation is of crucial importance:

a) Act no. 106/1999 on free access to information which also incorporates the European directive on re-use of public sector information. It represents the ius generalis in the field of public information. It also defines the supply side of public information that shall be made available in "the way that enables distant access" on the basis of activities of public authorities, or on the basis of applications made for them by citizens. The act presupposes a certain level of e-readiness of "legally bound subjects". This act also required secondary legislation that would specify some of the prescribed informational duties (e.g. today's special regulation of the former Ministry of Informatics no. 442/2006 prescribes compulsory structure of public information) (see e.g. Špaček, 2007). Relevant duties are shattered in various acts and other related laws (e.g. in act on information systems of public administration that presupposes accessibility of information systems to disabled people since 1. 1. 2008, and a related special regulation no. 64/2008 on accessibility of web pages; act on free access to environmental information (Act no. 123/1998);

b) Relevant duties are prescribed in the administrative procedure act (Act no. 500/2004). This act also presupposes electronic form of official notice board. Electronic notice board of an authority may be established indirectly, too, and that is to be done by making a public-law contract with other authorities in case of low capacities of an administrative authority to ensure publishing of content of notice board electronically. No specification of this incapability is prescribed however. The act on administrative procedure stipulates similar duties regarding the electronic registries, which are special workplaces of public authorities that should serve for receiving and delivering of data messages as defined in the act on electronic signature;

c) Act on electronic signature (act no. 227/2000) regulates the practice of this instrument in the Czech Republic. In case of interactions with public administration 
("guaranteed electronic signature"), this act also presupposes a more sophisticated form of e-signature.

d) Act on information systems of public administration (no. 365/2000) currently prescribes not only new accessibility requirements, but also general duties of "long-term management" of information systems. Within these duties, the act requires that administrative authorities elaborate and approve an "information conception" (in the period 2007 - 2008) that would address long-term aims of quality and security management, and general principles of buying, developing and running of their information system (as specified in special regulation no. 529/2006), too. The information conception shall utilize elaborating the second pillar of the ICT "long-term management" - documentation of the information system. Both of these parts shall be approved by a certification. Such a certification is not required with municipalities which exercise only the basic amount of state administration. The certification shall also ensure interconnection with other information systems. This act also prescribes special duties of the Ministry of Interior to administrate the Portal of Public Administration.

The Czech legislation which was passed in the last decade aims at reducing mutual incompatibilities of municipal information systems that is also important with regard to another specific feature of Czech public administration - municipalities (as well as regions) may also be responsible for state administration tasks (we speak about joined / mixed model of territorial public administration - see e.g. Špaček and Špalek, 2007). Taking into account characteristics of the joined model of territorial public administration, practices of Czech e-government projects always reflect characteristics of state administration and self-government. Centralization, hierarchy and top-down implementation of projects which intend to modernize in particular are distinctive features of state administration as a subsystem of Czech public administration. In territorial state administration, development of e-government is influenced / conditioned by national projects which are realized by individual branches of state administration (mostly separately by individual ministries), or in more resorts together with coordination of the Ministry of Interior. The national projects usually bring adaptation of information systems of municipalities and regions functionalities of which also cover the area of self-government. Currently, the following national state administration projects in particular are important for Czech municipalities and regions:

- Czech POINTs. The Czech POINT project represents a one-stop-shop project of the Czech central government which is still being developed under the responsibility of the Ministry of Interior. The project was tested during the year 2007 and has been in full practice since the beginning of 2008. Though a number of services provided by Czech POINT (which are also provided by municipal offices) has been growing and ministerial plans presumed that Czech POINT terminals would allow its users to proceed with any communication with any public authority at any place in the future, Czech POINTs still represent a network of physical terminals that provide Czech POINT reception services mostly during office hours of public authorities. They mostly do not deliver services to users on a $24 / 7$ basis via the Internet, but they transfer most of the requirements on its providers (for more information see e.g. Špaček, 2009). 
- data boxes (sometimes also as "data mailboxes"). Their practice has been legally facilitated by the so-called Czech "e-government act" (act no 300/2008 on electronic transactions and authorised conversion of documents) which came into force in July 2009. The act specifies data boxes as electronic communication instruments that shall simplify communication between public authorities and businesses and citizens. From July 1, 2009, all public authorities are obliged to communicate electronically with each other, and with certain private sector entities and individuals, using official data boxes. Data boxes are designed for sending and receiving official documents in an electronic form. The communication through data boxes is now compulsory in interactions inside public administration system (i.e. between authorities) and also in interactions between public authorities and corporate bodies which are registered in the Commercial Register (for more information see e.g. Špaček, 2010). Representatives from the Ministry of Interior usually distinguish data boxes from ordinary e-mails emphasizing by the fact that in the case of communication via data boxes security of communication is guaranteed (as well as funded) by the State.

- Czech eGovernment practice depends on effectiveness of legislation on basic registers. According to present information, in order to extend the testing period for one more year, basic registers shall be in full practice since 30. 6. 2012. The legislation specifies 4 basic registers (Register of Inhabitants, Register of Legal Entities, Register of Territorial Identification, Addresses and Real Estates, and Register of Rights and Duties) that shall replace many heterogeneous and often duplicate records of various authorities. In the case of the Information system of basic registers as well as of some of the basic registers (e.g. the Register of Inhabitants, the Register of Right and Duties), public tendering has not been finished or has finished only recently.

Strategy of e-government implementation in a territory may be also included into the documents which have coordination and standardization features and impact municipal and regional self-government. This strategy, which tries to further concretize aims that may be funded from the Integrated Operational Plan, was approved by government in December 2008. The strategy aims at establishment of eGON centres in regions that would facilitate ICT development according to local and regional needs. Working documents of the Ministry of Interior highlight the future needs of strategic planning (it presumes approval of eGovernment strategy of a region) and coordination activities of regions. According to the strategy, the regional and municipal eGON centres shall include (Špaček, 2010):

- technological centres allowing establishment, operation and maintenance of infrastructure necessary for processing key data of basic registers and other applications (e.g. file service systems, CzechPOINT@home). According to the Ministry of Interior, the project will link technological centres to the project of Czech POINT for municipalities, which will facilitate certain standardization of their ICT use even in the case of small municipalities. Current working documents also speak about a very important role of municipalities with extended competences (i.e. municipalities which have exercised the largest amount of state administration since 2003) - they shall become providers of technological centres for other municipalities. According to still deliberated plans, they shall primarily run electronic file service 
systems and other services like CzechPOINT@home1 for municipalities from their administrative districts. The planned criteria speak about effectiveness if such services are delivered for more than $50 \%$ of the municipalities from an administrative district of a municipality with extended competence in two years since the time of launching the project).

- administration and promotion of e-government, and

- e-government education including the support of implementation of central eLearning system.

CzechPOINT@home ("Citizen portal") represents a project which shall follow the Czech POINT project and build on good practices of municipalities and regions (see for example the projects like Virtuos, eSMO or eObec below) which have already implemented projects supporting electronic communication of public authorities with citizens. Its functionalities shall include life events, their connection with electronic forms, booking system (i.e. systems through which a citizen can book a visit of a municipal employee / regional office for a certain day and time), acknowledgement of status of administrative actions of citizens etc. The system shall be connected to basic registers and integrated into Czech POINTs.

Specific areas of e-government projects which may occur in Czech territorial selfgovernment represents those which are realized in territorially subdivided statutory cities and in the Capital of Prague. Statutory cities represents a group of cities whose specifics is their possibility to subdivide their public administration into a central level and a lower level represented by municipal parts / districts which, afterwards, have their own political and administrative bodies. The municipal parts - if established - have restricted legal status which source from legislation and the called "status" - legal document approved on the central level of a statutory city (by its central council) which defines organization of public administration on the central (statutory city) level and on the levels of municipal parts. We cannot speak about autonomy of municipal parts as the legislation does not give them independent legal status, they are not independent legal entities, but only "organizational units" of a statutory city whose property, amount of self-government, as well as state administration depends on decision of central council and central authorities. The status of municipal parts of the Capital of Prague is rather different; the legislation gives municipal parts of Prague their independent legal status, however, when it comes to the area of their economy, their status is similar to the status of municipal parts of statutory cities.

The mentioned national strategies and supplementary specifying documents builds on the fact that regions and municipalities are not in subordination relationships in the area

1 Ministerial plans speak about "typified projects". Regional technological centers and technological centres of municipalities with extended competences shall ensure required functions of the following: a) typified projects of self-governments: electronic file service system, digital map of public administration (cadastral map, territorial planning and analytical documents), data depository and managerial information systems for regional statistics, saving and digitalization of data, CzechPOINT@home, management of crisis; b) already defined projects of self-government (ePUSA as a database of contacts on self-governments, KEVIS as a central depository of basic structured data, and HelpDesk for communication within a region or administrative district of a municipality with extended competences). 
of self-government. E-government practices cannot be commanded in any other than legislative way, and only good practices may be spread. Cooperation is voluntary, but in situation, where it has evolved, it is perceived as beneficial. The national plans stem from the assumption that the most advanced personnel and technologic background is at disposal particularly on the level of regions and statutory cities. Offer of other services, which should be realized through the "typified projects" (see above), is possible on the regional level in cooperation with municipalities with extended responsibilities. This is the backbone of the future system (Ledvinka a kol., 2009).

\section{Czech national e-government awards and characteristics of awarded regional and municipal projects}

In the Czech Republic, practice of e-government is annually evaluated by various awards. Annually, it is also presented during the ISSS conference, which takes place in Hradec Králové every spring and focuses particularly on presentations of practitioners from private companies, municipalities, regions and central authorities rather than of the academia. Czech e-government projects are also introduced during the autumn INVEX trade fair. The following competitions are apparently the most famous and thus most medialized national e-government awards - competition The Best of the Egovernment.cz magazine, Golden Crest of national awards for innovation in public administration of the Ministry of Interior. The text below firstly summarizes the philosophy and the criteria of these competitions, and, secondly, it summarizes information about the projects awarded / medialized.

Initially, the author wanted to use the classical categorization of e-government projects into G2C (Government-to-Citizen), G2B (Government-to-Business) and G2G (Government-to-Government) projects in the summary. Since it was apparent that several projects include services from more or all of these categories, the final summary is based on an assumption that it is obviously more practical to categorize awarded / medialized projects according to their substantive / material focus (in spite of the fact that for example The Best of the Egovernment.cz magazine competition uses the summarizing abbreviations $\mathrm{G} 2 \mathrm{C}, \mathrm{G} 2 \mathrm{~B}$ and $\mathrm{G} 2 \mathrm{G})$.

2.1 National awards for innovation in public administration and awarded e-government projects of territorial self-government

National awards for innovation in public administration of the Ministry of Interior have been awarded annually within the framework of National quality awards in public administration since 2005. The award for innovation shall - according to its specifications - be awarded to new and not traditional ideas which may serve as good practice examples. It is not awarded in golden, silver or bronze categories, only the award for innovation is given as itself.

Criteria of the award are annually specified by Statute of awards of the Ministry of Interior for quality and innovation in public administration. The Minister of Interior approves the Statute upon recommendation of members of Expert section of quality in public administration of the Council for quality of the Czech Republic. The Expert section discusses applications for awards and decides which of them will be included in the competition; it also proposes to the Minister of Interior those that should be awarded 
the prize, decides the conflict cases and, eventually, about sanctions in cases of violation of the competition rules. It also appoints evaluators of applications who elaborate evaluation reports which shall include a proposal of awarding / not awarding a prize.

In the period $2005-2010$, Statutes of awards for innovation in public administration enumerated the following criteria:

- A solution must apply a new approach or an innovative way of application of existing instruments, which provably brought about improvement in activities or increased quality, economy, suitability or efficiency of public service delivery. The level of innovation must be documented by evidence, the application for competition requires applicants to state criteria of goals achievement.

- A solution shall be applicable in other organizations of public sector, which means that it shall serve as a good practice example and inspiration.

- The award will be given to those organizations which prove accomplishment of goals stated in the application in its final report.

- Since the 2010's awards, which were announced in February 2011, it has been required that competitors must prove that their innovative project is carried out for at least 1 year.

Information about e-government projects of territorial self-governments (municipalities and regions) which were awarded a prize for innovation in public administration is summarized in the table 1 (in the appendix). The table summarizes awarded projects according to their substantive focus. It shows a variety of breadth of individual projects and also a decomposition / allocation of awards in the period 2005 - 2010. In some cases, the categories used for summarization contain more broad sub-categories (e.g. portal solutions). Awarded projects were included in the table particularly according to the breadth of their implementation which was actually awarded. It is necessary to point out that the majority of services was developed on the order that authorities placed in private sector. Projects were often funded from structural funds of the EU or (to a lesser degree) by Norway grants. The table shows a decomposition of project types in time; to a certain extent, it also summarizes development of electronization in some authorities (e.g. in the case of municipalities or regions which received the award repeatedly).

In 2005, 10 authorities were awarded the prize in total, 4 of them were municipalities which received the award for their e-government projects. Two categories of projects were awarded. Among those services offered to the public were those that supported the service to clients within the premises of authorities (e.g. Chomutov was awarded for the possibility to pay by credit cards in more terminals, which reduced the necessity of citizens to pay at the cash desk situated in one building of the municipal office only, or for the possibility to apply for an appointment with a civil servant by an SMS or using the Internet). Another project that was awarded was that of České Budějovice to transmit municipal council's sessions in cable TV or online, where archived videofiles of sessions were available, too. Among projects related to services, which were designed for public as well as for internal needs of public administration, geographic information systems (GIS) in particular were awarded, some of which also allowed smaller municipalities to coordinate their work on uniform map depository of a region (this was the case of Děčín municipality). 
In 2006, 12 authorities received the award, 7 of which were municipalities and regions which were awarded for their e-government project. In this year, electronic support of service to citizens within premises of the authority was awarded, too (e.g. the calling facilities and self-serviced Internet application for visiting the municipal office in Přrerov).

Compared to previous year, services which were designed only for internal needs of individual public authorities were awarded, too. This was the case of information system of Jablunkov (whose application was very brief and did not contain sufficient information in my opinion, it only briefly enumerated goals), economic integrated systems of organizations established by a region (e.g. the IS of Karlovarský region, which focused on economic agendas of more than 100 of its allowance organizations and enabled their better control), intelligent forms used for satisfaction measurement of allowances organizations established by Olomoucký region, which were integrated into its regional economic IS. Internal needs were the motive for project digitalizing an archive of the building and construction department (which represents one field of responsibilities of larger municipal offices) of Chomutov's municipal office in particular.

A project which intended to spread good practice was also awarded - the "Dataplán" of the network Healthy Cities of the Czech Republic (which was established in cooperation with the Region Vysočina) which also contains elements of managerial IS. It shall serve municipalities, their voluntary associations ("micro regions") and regions to monitor which financial resources and with what effect are allocated to strategic priorities. The Dataplán also enabled to compare projects between / among municipalities and regions, and serves as a depository of projects which are to be / were evaluated within the regional policy funding framework, too.

Compared to previous year, projects from the $\mathrm{G} 2 \mathrm{C}-\mathrm{G} 2 \mathrm{~B}-\mathrm{G} 2 \mathrm{G}$ category (i.e. services designed for the public as well as for public authorities), which were constituting a metropolitan network, were awarded, too. This was also the case of projects which were not finalized. This was the case of "eSMO" Information system of the statutory city of Ostrava. In the time when it applied for the competition, the infrastructure comprised of 21 self-serviced information kiosks, 10 serviced information receptions situated in authorities of municipal parts, 3 public Wi-Fi hotspots enabling broadband access to the Internet and 1 contact centre and technological infrastructure for service delivery. Services in an innovative way (i.e. using the web www.esmo.cz, e-mail, SMS, information kiosk, information reception or phone) related to the agenda of documenting and issuing of personal IDs, or to the agenda of waste disposal, were offered. In the case of personal IDs, a citizen might pre-fill an application form for an ID card. Electronization of other agendas was prepared. The transactional e-services were conditioned to prior agreement between a citizen and the authority upon which the citizen received the log-in data for accessing the private part of the portal. Without these data a citizen could gain access only to public information related to life events, activities of individual bodies of the city etc. The agreement could be made in person in public authority, those who owned the e-signature could also use e-mail.

In 2007, 5 authorities received awards for innovation. 4 of those authorities were regions and municipalities with e-government projects. Again, projects utilizing new 
instruments for communication with citizens were awarded - the use of Skype to communicate with municipal office of Koleč for free and self-serviced handling of selected administrative operations by SMS messages (the project "Phone Book") in Chomutov (the project allows citizens to initiate some administrative operations by an SMS - e.g. the application for verification of number of points in the register of drivers, the price of the SMS includes the administrative fee, a citizen is also informed about issuing of a document by an SMS etc.).

Projects of internal economic and managerial IS (it was the case of Hlučín) were awarded, too. Data depository of Vysočina region is an example of awarded internal IS project which has a different dimension. The data depository was established due to an increasing amount of data necessary for decision-making and the increase of costs connected with their processing. Establishment of the data depository allowed according to the application to the competition - that civil servants core work activities now focus on data analysis rather than on creation of tables. The application pointed out the "disgust" of some civil servants to accept new methods of work with data and to learn.

In 2008, 12 authorities were awarded a prize for innovation. 8 of these authorities received it for e-government projects in territorial self-government.

Among projects which utilize new instruments for communication with citizens, we may include the "Mobile authority" project of Municipal Part Prague 10 which allowed civil servants (armed with a notebook with a VPN access to IS) to visit elderly people in their homes in order to handle administrative tasks from the field of social allowances etc.

In our category of services for the public, the prize was awarded to the Portal for cyclotourism of Jihomoravský region was awarded a prize.

In the category of internal economic and managerial IS, we may include the portal of strategic management of the Region Vysočina, thanks to which employees of the regional office and members of regional board (i.e. one of political bodies of a region) can find information from the field of strategic management, quality management and in the future - as is planned - information from processes management, too. The portal also comprised of a dynamic element which evaluated key indicators of quality management and showed deviations against strategic goals (in the time of application, 11 of 33 strategic aims could be monitored in this way). All information was available to all employees, not only to selected top-managers. In the category of internal economic and managerial IS, we may also include a new system of handling debts in the municipality of Šumperk which attempted to simplify a system of fees from citizens in the self-government, using the SIPO of the Czech Post (the SIPO enables citizens / organizations to cumulate payments for other individuals / organizations which made a deal with the Czech POST to enable the SIPO to make only one payment).

Another awarded project - that of municipality Hodonín - followed the DataPLÁN project which had been awarded a prize in 2006 , and enabled creation of an action plan of a municipality taking advantage of a project on-line depository. This project is included in the third category of services of grant allocations / public procurements, because - according to available information - it enabled external organizations (and 
also organizations established by the municipality) to send project proposals to the municipal office. Application Softender of the municipality Studénka which intended to ensure remote access to project documentation to applicants for public procurements, and enabled handling public procurement agenda (establishment, publicizing, evaluation, applicant selection, archiving) electronically, is another project from this field, which was awarded this year.

This year, a prize was awarded to one of large and largely medialized projects which goes beyond establishment of regional communication infrastructure. It was the case of VIRTUOS project of Plzeňský region. Its functions covered duties of municipalities. The aim of the project was to proactively try to address problems of middle-size and small municipalities to comply with the legislatively stipulated duties, as well as to offer e-services which were considered standard - e.g. booking of time for visiting public authorities, a possibility of a citizens to monitor status of handling of their submissions to the authority and to archive his/her activities with the authority from the category of services for citizens, or electronic file services which could be used by municipalities that had not established it. The project intended to initiate creation of standards and became the inspiration during implementation of the national strategy for e-government implementation in territories (see above).

The table 1 does not include a project "registration place" of Municipal part Prague 13 which received a prize. This project enabled citizens to register and apply for esignature of a private company (for lower purchase prices).

In the case of projects which were awarded a prize for innovation in 2009 and 2010, we do not have more information that was formerly available in the form of applications. Only Powerpoint presentations prepared for the purposes of the national quality conference are available.

In 2009, 6 authorities of municipalities and regions were awarded, 2 of which for egovernment projects - the municipality Jablunkov for improving navigation for searching employees of its municipal office, and Plzeňský region for its "electronization of internal processes". In this case we have more information, because the project was awarded in prize in other competitions (see below).

In 2010, 3 authorities were awarded a prize, 2 of which were municipal and regional egovernment projects - Zlínský region received a prize for its "information management", and the municipality Vsetín for dynamic strategic plan of the Balanced Scorecard which was handled by software simulating strategic development scenarios according to changes in model parameters.

\subsection{The Golden Crest competition}

The Golden Crest competition awards the best websites and electronic services of municipalities. Its state-wide results are annually announced during an ISSS conference (see www.isss.cz). The competition is organized in cooperation with Association of municipalities, Association of regions, Ministry for Regional Development or Ministry of Interior and association Český zavináč (Czech @) and portal Towns and Communities Online (see http://mesta.obce.cz/summary_english.asp) . 
The competition wants to support modernization of local and regional public administration through development of electronic services delivered to citizens, and increase of quality of life in towns, communities and regions. The competition is firstly organized on the regional level, and the finalists of regional rounds compete in statewide competition. In this paper only projects which were among the finalists of the state-wide competition are summarized, again with reference to the period of 2005 2010 (the awards in the category "Best electronic service" was firstly awarded in 2004).

Information about e-government projects of territorial administration (municipalities and regions) which were in the first three places, is summarized in the Table 2 (in the appendix) similarly to the previous competition. It is necessary to point out that the summary is more problematic compared to the awards for innovation of the Ministry of Interior or to the competition The Best of the magazine Egovernment.cz. In the case of the Golden Crest competition, applications or summaries of projects (based on the content of applications) are not available, only chart of awarded projects (sometimes, but not always supplemented with links to awarded e-services) is published on the website of the competition, sometimes also scoring of individual projects as received by individual members of evaluation teams are available. The focus of awarded projects was deduced from the names of the projects. In case of some of them, more information can be found because these projects were awarded in different national competitions, information about others can also be found on web pages of municipalities, because majority of e-services are still provided.

In 2005, the Map of municipality Beroun and its surroundings was awarded in the category of services from the field of tourism. Municipality of Přerov received the prize for electronic support of customer service (citizens could monitor carrying-capacity of selected departments of municipal office, book time for their visits of the municipal office, and also to monitor the process of their submissions in the case of personal IDs). Similar services (booking system and process monitoring) were the reason for an award for municipal office of Vyškov. In this case, we may found many commentaries on the web pages of this municipality which complained that the service, which would help them to get information about capacity-carrying of department responsible for driving licences, was not available during the rush hours (caused by situations where vast majority of citizens changes their driving licences as required by legislation in certain deadlines on the last moment). We may also find here the following commentary: "Well, who wants to make appointment to change/getting a driving licence through e-registry office till the end of the year, they must be very fast just before midnight. Today, all the available times for December 20 were occupied in less than a minute... I managed to get one :-). So I wish others good nerves and very fast fingers on keyboards :-)".

Municipality of Brandýs nad Labem was awarded in 2006 for online booking of appointments (which enabled also booking via SMS) and for information of handling the clients of the department of transport available online. The case was very similar with municipal office of Most which received a prize in the Golden Crest competition for E-applications of citizens. This year, online transmissions of sessions of city council of statutory city České Budějovice were awarded, too.

Municipality of Brandýs nad Labem received a prize in 2007 for its increase of number of services thanks to which it is possible to make the appointment online. This town was 
also awarded for its project of SMS news services. Municipal part Prague 6 also received a price for utilization of new instruments in communication with citizens (its project "Local MMS-ing" - see below). This year, currently operational project eSMO establishing a G2C-G2B-G2G metropolitan network (comprising services designed for the public, as well as for public administration as introduced above with regard to awards for innovation) was also awarded.

In 2008, municipality Bohumín was awarded a prize for utilizing new instruments of communication with citizens, specifically for the service E-info. The service allowed citizens to obtain various information - a citizen, who registered himself/herself, can choose which information may be - subsequently send to his/her e-mail or by an SMS. According to currently available information, the service is free of charge. Informational features have other awarded projects - TV6 of Municipal part Prague 6, or the service e-Museum Senorady (see below).

In 2009, another development of IS eSMO of statutory city Ostrava was awarded. Currently, the IS offers the following:

- information about handled administrative responsibilities (office hours, necessary documents, legal deadlines etc.)

- booking system (booking of day and date of the visit of municipal office departments or offices of municipal parts; it is also possible to make the reservation by phone)

- free Internet access in offices of municipal parts through information kiosks and in the municipal library

- Wi-Fi Internet access for lower prices

for registered users (who make an agreement with the city), the IS offers online booking, access to e-forms, preview of handled affairs and running processes, and also an SMS / e-mail announcement of finalization of the process under way.

In 2009, municipality of Přibyslav also received a prize for transmission of sessions of municipal councils in cable TV and online availability of archived videofiles of these sessions. Municipality of Semily was awarded for making it possible for citizens to announce defects and problems by an MMS - this service (similarly to formerly awarded Local MMS-ing of Municipal Prague 6) allowed citizens to send a photo with accompanying message by an MMS or by e-mail.

In 2010, the Capital of Prague was awarded for its portal Public Procurement Under the Eye Loupe which provides applicants as well as the public with information about planned and proceeding public procurement. Published information were related to building procurements (with prices over CZK 1,000,000) (the portal goes beyond legal duties, because the Czech law defines more duties in case of public procurements with price over CZK 2,000,000).

This year the GIS - conception of territorial plan of the municipality Šumperk and also e-Museum Senorady were also awarded. The e-museum offered a guided access to historical information and 3D exhibits of town which have not been established by the "stone" museum. 


\subsection{The Best of the magazine Egovernment.cz}

The aim of The Best of Czech magazine Egovernment.cz project is to annually gather and present the most interesting e-government projects from the national and territorial level. In the project, we may distinguish projects which were among the three winners, and those which were considered to be the most interested in a year (including the three winners) and were medialized by the magazine. The summary below covers this broader category which is considered to be The Best projects of the year and focuses only on projects of municipalities and regions.

In the competition, projects could be applied which aim at improvement of efficiency of public administration and increase of user / citizen comfort. A project could be applied or can be drawn attention to by anybody regardless of the size of a project or its focus. Who will and who will not be among the finalists, that depends on voting of readers of the magazine, and particularly on decision of evaluation commission (based on scoring), whose members were representatives from the area of public administration and ICT experts. Among evaluators, the commission also included representatives from institutions which were awarded the prize!

Since 2007, the competition organizers have categorized the selected and medialized projects into the following categories: A - infrastructure, B - services for internal needs of an authority, $\mathrm{C}$ - services for the public, D - education. Individual projects were also summarized by abbreviations G2C, G2B, G2G. Since it was not possible to compare the projects due to their heterogeneity and different size mutually, the criteria which were used for scoring were based on the criteria of the European eGovernment Awards according to the organizers of the competition. Since 2007, the competition has been using the following criteria and these were used during evaluation and in decisions if a project was to be presented to the public:

- demonstrability of results and impact of project / solution, relationship between benefits and costs,

- demonstrability of best practice, or the potential for transferability,

- multichannel aspects are taken into account,

- improvement and effectiveness of management - whether the managerial approach is innovative, how efficiently does it work with technological instruments,

- overall impression and communication capacities (whether there is a compelling way of presentation and whether the solution is extraordinary or not).

- In later years the criteria also contained criteria whether users (target group) perceive and find the project beneficial, and to what extent they are aware of the project, and if projects have short-term or long-term effects.

In 2008, projects were presented in the form of answers to questions from the application which were based on the mentioned criteria. Publicly available information about projects indicate that the information stems from the verbatim content as stated by applicants. In the vast majority of cases, the available description of projects which were among The Best projects and medialized / presented as such, contains a brief and particularly qualitative description of aims, anticipated benefits and real impacts, rather 
than quantitative description as required by the criteria (the application presumes that applicants gives deeper reasons for their argumentations, it wanted to award those who used the IPAT or eGEP methodology of impact measurement).

The table 3 (in the appendix) summarizes information about projects, practice of which was presented in the Egovernment magazine from 2006 (this was the first year of the competition) to 2008 and in 2010 (in 2009 the competition was not organized).

\subsubsection{The Best projects of 2006}

In 2006, seventeen projects of municipalities and regions were presented as The Best projects. In comparison to previously summarized competitions, among those of them which related particularly to e-services of the G2C/G2B the smart card of Plzen ("Pilzen card") was awarded. It has been offered since May 2004. The project implementation was divided into 4 phases - during the 0 phase, the card was supposed to be launched in practice, during the phase 1 , its functionalities were supposed to include identification functions of the card in other independent systems (entrance, attendance, school, provision of meals etc.), during the phase 2, payment functions of the card were supposed to be introduced (outside the public transport, where the use of cards was initiated - in libraries, by transport companies of the integrated transport system, parking places, sports or culture facilities, in a zoo etc.), during the phase 3, authorization functions were to be enhanced using the e-signature functions in agendas of state administration and self-government. According to information available, the Pilsen card has reached only the phase 2 and also allowed replacement of ISIC student cards.

In this competition, we may also found projects awarded for implementation of electronic support of citizens within premises of public authorities (booking system and services that enable to monitor the number of client services in municipality Přerov or a similar service, which also included an SMS canal, as in the case of municipality Děčín). Also the project of Praha5.net Internet for Free was presented among the best projects within which 16 HotSpots for Wi-Fi access were established (registration which had to be passed prior to access in order to get log-in data required long-in name, password and e-mail address).

In 2006, regional information communication networks designed for larger administrative territory (i.e. larger than a territory of a single town / region) were awarded. The example here could be the network ROWANET (project of the Vysočina Region) which offered high speed Internet, roaming (Wi-Fi access points), public Internet (Wi-Fi through hot spots situated on public places), services of high capacity depositories, hosting of applications based on HTTP protocols, VPN, or services for other public authorities (hosting of e-registry office). More limited were functionalities of other awarded project of this type - the non-public data network of the Capital of Prague MePNet.

In The Best project, another initiative of the Capital of Prague was medialized this year - the current project of city portal which should enable citizens to communicate with the city office through interactive forms which can be not only filled in, but also sent; citizens can also monitor the phase of their processing. The portal also enabled 
personalization in the "My Prague" section. Atlas of Environment of Prague project was also medialized, which - based on thematic yearbook - comprised of GIS on air, water, landscape, waste, noise, etc.

Municipality of Zábřeh was among the three finalists awarded for implementation of ICTs in the area of human resources management. The project was supplementary to attendance monitoring system and focused particularly on monitoring of activities of municipal office's employees. Following information about activities which were exercised on PCs were recorded into a log file, including the activities on the Internet. Similar projects have been also implemented in the private sector. Currently a decision of the regional court of České Budějovice from February 2011 is important, since it allowed firms to fire their employees if they spend more time browsing the Internet without former information that their online activities are monitored.

From the group of projects which relate to internal functioning of public authorities, the project of electronic handing over of documents within the territory of Municipal part Prague 9 was also awarded. According to the information available, the project was expected to bring efficiencies in exchange of documents between authorities using the infrastructure of the Capital of Prague (that is also why the project is included in the category "file service systems").

In 2006, other GISs were also awarded - the project Development of water piping and sewer system of Kralovéhradecký region and Map portal of statutory city Plzeň. In the case of Plzeň, The Best initiative of the magazine Egovernment.cz also presented development of its internal IS which was built on SAP, and enabled data interconnection of individual buildings of the city office, offices of municipal parts and allowance organizations established by the city (e.g. Pilsen municipal transport utilities, Municipal establishment for social services, Municipal police) and it also connected some institutions administered by the Regional office of Plzeňský region, Westbohemian University, Faculty of Medicine, Teaching Hospital Plzeň and other. That is why the project is included in the subcategory metropolitan network. In the phase of analysis was a project from front-office area - a system for creation of forms and data collection, monitoring of the process of citizens' submission, possibility to use other instruments for payments etc. The focus of medialized metropolitan network and portal of municipality Pelhřimov was similar.

In 2006, the project eCity-council of statutory city České Budějovice was also awarded. It consisted of electronic voting equipment which enabled presentation, application for discussion and voting. Voting results were evaluated by software and printed simultaneously, graphical output was also presented during the session of the city council. Archived audio file was made available on website of the city, as well as results of voting related to points of the session programme discussed .

Introduced system eSMO of the statutory city Ostrava was awarded which is included in the subcategory infrastructure of regional communication network within a metropolitan area which is expanding into G2C / G2B dimensions. Other project of this type is represented by the network iNOVOMĚSTO which was initiated by municipality of Nové Město na Moravě. Within this network, 38 interactive information kiosks with public free internet access existed. Information kiosks were also situated in 19 
municipalities. The goal was also to connect municipal offices to metropolitan network through VPM. Other goals included improvement of attractivity for tourism.

\subsubsection{The Best projects of 2007}

In 2007, 11 projects of municipalities and regions were presented. Among internal economic and managerial ISs, which were presented as best projects in 2007, we may also find IS for administration and filing of real estates of the Capital of Prague, of economic system of Municipal part Prague 1. The Municipal part Prague 1 also gained the attention for its new instrument for communication with citizens - a system of delivery of information and warning and security announcements by an SMS. Among the projects of Municipal parts of Prague, the "Regional communication service" was also medialized, its aim being to ensure Wi-Fi access of citizens to communication with the municipal office It was again supplemented by information kiosks with Internet access. A project of the Municipal part Prague 10 which focused on e-learning applications in order to improve education of civil servants of municipal office of this part was medialized, too. This initiative raises questions why the Capital of Prague or the Ministry of Interior as the central institution for education of civil servants does not support similar projects.

A project of preparation of electronic materials for sessions of political bodies (council and board) of municipality of Uherský Brod could be found among the awarded projects.

The VIRTUOS project of Plzeňský region that we have already introduced was also medialized in The Best initiative in the e-government projects. GISs also gained attention in this year - cadastral map of Zlínský region, which was designed only for needs of public administration (according to available information it could be used by the regional office of Zlínský region and, on the basis of agreement, also by other municipalities from the region). GIS "Mapping of camps in Vysočina" which enabled its users to obtain information about concrete localities of camps, including the contact data, number of participants, access an Integrated security system to inform - via an SMS - the head of the camp about any emerging danger - floods, windstorms, police announcements etc.

In comparison to previously summarized competitions and projects, which were awarded in this competition in future, the statutory city of Ostrava was medialized for its transport camera surveillance system, or, the statutory city of Plzen for its uniform school IS PilsEDUnet, which enabled teachers, parents as well as pupils to access information from various fields (e.g. studying results, school attendance, school events, educational activities etc.).

\subsubsection{The Best projects of 2008}

In 2008, 9 projects of municipalities and regions were presented among The Best egovernment projects, 2 of which were also awarded among the finalists. The project eObec of municipality of Uherský Brod - one of the awarded projects - offered modular system solution of a private company for communication between municipalities, regional offices, their organizations and citizens. It is the project from the category of 
infrastructure of regional communication network within a metropolitan area which is expanding into G2C / G2B dimensions. The VIRTUOS of Plzeňský region which initiated standardization on the larger territory and which has been already introduced, is yet another project which was awarded.

In this award there were also projects which had been awarded in previously summerized competitions - e.g. project of data depository of Vysočina region or the Phone Book of municipality Chomutov. This year, other projects were repeatedly given the attention by the magazine Egovernment - e.g. system for information and security announcement of the Municipal part Prague 1 which was also medialized thanks to creation of free 24/7 call centre integrated in to system of solution monitoring. Among the services for the public, tourist portal Výletů ráj (Heaven of Trips) was presented, which also enabled its users to find out a profile of a journey or to generate its GPS data. In the case of services designed for internal use, file service of Statutory City of Brno (which was used also by its municipal parts) was presented.

\subsubsection{The Best projects of 2010}

In 2010, 7 e-government projects of municipalities and regions were presented among The Best projects by the magazine Egovernment.cz. Again, we may find GIS among the projects - Unified portal of analytic territorial documents and territorial plans of Zlínský region which was established thanks to its cooperation with municipalities with extended responsibilities from the region. The project which can be used by the public was an inspiration for one of typified projects of IOP (its subpart Improvement of egovernment services in regions). Another project of this region was presented in the best projects - the electronic collection of applications for support from the programme fund of the region.

Electronization of internal processes of the Regional office of Plzeňský region (which was also awarded a prize for innovation of the Ministry of Interior in 2009) can be found among the awarded project, too. Presented information emphasizes that majority of public authorities did not electronize so many internal processes as the Plzeňský region and that the established information system became an inspiration for about 8 other regions (there are 14 regions in the Czech Republic, including the Capital of Prague). Prior to electronization of internal processes, process analysis was carried out in 2003. Electronization of internal processes was launched in 2004 and according to the project specification, the level of innovativeness is related particularly to areas where there is not such great electronization (invoices, travel orders etc.), or where the electronization is not so complex and integrated.

On the internal environment of a public authority another presented projects were focused - electronic confirmation of internal documents by employees of municipal office of Karviná which was build on intranet employee portal, where electronic documents were filed, or the digitalization of documents of construction department of municipal office of Litomyšl, which should also protect historical materials and layouts. The GIS of Dvůr Králové nad Labem which focused on internal needs of property administration was presented, too. 
Among services focused on G2C / G2G aspects, calendar of events of municipality Nymburk was presented, which aimed at increase of information about cultural and sport events in the region.

\section{Conclusive notes}

The paper summarizes trends of electronization in Czech territorial self-government on the basis of information about projects which were awarded / presented in the most famous Czech state-wide e-government competitions. It shows that the practice is heterogeneous, projects of various breadth and depth were awarded. Many of them were awarded repeatedly during individual phases of their implementation.

The summary of focus of projects which were awarded in the period 2005 - 2010 may be summarized in the table 4 (in the appendix). The table shows that projects which were based on services for the public in particular were awarded in the surveyed period. Most of the projects were from the subcategory of electronic support of service to customers within premises of a public authority, which includes establishment of electronic calling and booking systems supplemented usually by SMS-messaging, and from the category of new instruments for communication with citizens / businesses in administrative agendas, which comprises of call centres, electronic booking systems, SMS-/MMS-ing or using skype for communication with public authorities. Incremental nature of change which focuses on improvements of comfort of citizens and not necessarily requires larger funding is the common feature of these projects.

The second category of services in which most awards were granted was represented by services designed especially for internal needs of public administration. Here economic and managerial information systems of various breadth and depth in particular were awarded. In the case of municipalities and regions, similar projects were launched due to changes in organization of public administration in the period of $2000-2002$, which brought abolishment of former district offices and transfer of their responsibilities to new municipalities of extended responsibilities or regions (in this case particularly the transfers included changes in bearers of the functions of founders of various organizations). They attempted mainly to enhance uniformity and control instruments.

The group in which the e-government projects were not awarded so often is represented by the category services designed for the public, as well as for public administration. This group is not important due to the number of awarded projects, but because of its subgroup of projects I called infrastructure of regional communication network within a metropolitan area which is expanding into G2C / G2B dimensions, and subgroup projects offering communication infrastructure in order to standardize internal and external processes (similarly to the project Virtuos). A very deep focus of electronization which usually presupposes larger reorganizations of their back offices is the common feature of these projects.

Although the paper is based on secondary data, it shows some existing directions of innovations. Although the paper focuses primarily on the supply side of e-government, it raises questions which may be the scope of future case studies which would also deal with citizen- and demand-centricity of selected projects, for example. The questions may be also raised concerning the criteria used in competitions. According to 
supplementary information which is published about the awarded projects, it is apparent that applicants for awards usually do not specify anticipated and real impacts of their projects in a deeper way, although such information is anticipated by specifications of awards or by their applications. Therefore, a future analysis that would focus on managerial aspects of e-government implementation and user satisfaction would be beneficial.

\section{References}

ACCENTURE (2009). Web 2.0 Collaboration Tools for the Next Generation of Public Service. Accenture, Retrieved October 25, 2011 from http://www.accenture.com/usen/Pages/insight-web-2.0-collaboration-tools-public-service.aspx.

CRIADO, I. (2009). Public Administration in the Age of the Web 2.0. How and What for Public Managers and Agencies are Blogging?. EGPA 2009 conference papers, Retrieved October 25, 2011 http://www.egpa2009.com/documents/psg1/Criado.pdf.

GRAND, G., CHAU, D. (2005). Developing a generic framework for e-government. Journal of Global Information Management, 2005, Retrieved June 23, 2008 from http://www.accessmylibrary.com/coms2/summary_0286-18298874_ITM.

Information on criteria and results of The Best competition of the magazine eGovernment.cz (concerning the researched period of awards) (http://www.egovernment.cz/).

Information on criteria and results of the Golden Crest Competition (concerning the researched period of awards) (http://zlatyerb.obce.cz/).

LEDVINKA, R. ET AL. (2009). Technologická centra krajů a obcí s rozšírenou působností, včetně spisových služeb (Koncept a východiska). Praha: Ministerstvo vnitra ČR, online, 14. 4. 2009.

OECD. OECD e-Government Studies: Belgium, 2008, Retrieved October 26, 2011 from http://www.oecd-ilibrary.org/content/serial/19901054.

OECD. OECD e-Government Studies: Netherlands, 2007, Retrieved October 26, 2011 from, http://www.oecd-ilibrary.org/content/serial/19901054.

OECD. Rethinking e-Government Services: User-Centred Approach. OECD, 2009, Retrieved December $\quad 16, \quad 2009$ from http://www.oecd.org/document/7/0,3343,en_2649_34129_43864647_1_1_1_1,00.html.

OECD. E-Government Imperative. OECD, 2003, Retrieved December 16, 2009 from http://www.oecdbookshop.org/oecd/display.asp?lang=en\&sf1=DI\&st1=5LMQCR2JF94 1.

SNELLEN, I., THAENS, M. (2008). From e-government to m-government: towards a new paradigm in public administration?. Promotion seminars - Administrative innovation, International context and growth, Bologna, 2008, Retrieved December 12, 2009 from http://unpan1.un.org/intradoc/groups/public/documents/CAIMED/UNPAN028992.pdf. 
ŠPAČEK, D. (2007). Principle of openness and transparency and the criteria for egovernment evaluation in the Czech Republic. In Eastern Europe eGov Days 2007 Best Practice and Innovation. Wien: Österreichische Computer Gesellschaft.

ŠPAČEK, D. (2009). Czech POINTS - The Czech Showcase? In State and Administration in a Changing World. Bratislava: NISPAcee, 27 pages.

ŠPAČEK, D. (2010). E-Government management and evaluation in the Czech Republic - shifts in practice? In Public Administration in Times of Crisis. Bratislava : NISPAcee, 21 pages.

ŠPAČEK, D., MALÝ, I. (2010). E-Government Evaluation and its Practice in the Czech Republic: Challenges of Synergies. The NISPAcee Journal of Public Administration and Policy, 2010, Vol. III, No. 1, pp. 93-124.

ŠPAČEK, D., NESHYBOVÁ, J. (2010). Brief history and current trends of public administration reform in the Czech Republic. In Public Administration in Times of Crisis. Bratislava : NISPAcee, 18 pages. ISBN 978-80-89013-52-4.

ŠPAČEK, D., ŠPALEK, J. (2007) Communication and Electronic Public Administration: Some Issues in the Context of the Czech System of Public Administration. In Lessons and Recommendations for Improvement: Central and Eastern European Public Administration and Public Policy. Bratislava: NISPAcee, pp. 217-238.

ŠPAČEK, D. (2012) E-Government - cíle, trendy a přístupy k jeho hodnocení. Praha: C. H. Beck. (in press).

Statutes of national quality awards and information on results published by the Ministry of Interior (concerning the researched period of awards) (http://www.mvcr.cz/clanek/verejna-sprava-podpora-zavadeni-kvality-ve-verejnesprave.aspx). 


\section{Appendix}

Table 1: Types of projects which received the award for innovation of the Ministry of Interior in the period $2005-2010$

\begin{tabular}{|c|c|c|c|c|c|c|c|c|c|c|c|c|}
\hline \multirow{2}{*}{$\begin{array}{l}\text { Types of awarded projects } \\
\text { according to the focus of } \\
\text { their services }\end{array}$} & \multicolumn{2}{|c|}{2005} & \multicolumn{2}{|c|}{2006} & \multicolumn{2}{|c|}{2007} & \multicolumn{2}{|c|}{2008} & \multicolumn{2}{|c|}{2009} & \multicolumn{2}{|c|}{2010} \\
\hline & No. & M/R & No. & M/R & No. & $\mathbf{M} / \mathbf{R}$ & No. & M/R & No. & M/R & No. & M/R \\
\hline \multicolumn{13}{|l|}{$\begin{array}{l}\text { 1) Services designed } \\
\text { especially for public }\end{array}$} \\
\hline $\begin{array}{l}\text { electronic support of } \\
\text { service to customers } \\
\text { within premises of a } \\
\text { public authority (e.g. } \\
\text { terminals for credit card } \\
\text { payments, calling } \\
\text { systems) }\end{array}$ & 2 & $\begin{array}{l}\mathrm{CH} 1, \\
\mathrm{CH} 2\end{array}$ & 1 & PRER & & & & & & & & \\
\hline $\begin{array}{l}\text { increase of information } \\
\text { about activities of } \\
\text { political bodies } \\
\text { (municipal / regional } \\
\text { councils or boards) } \\
\text { (e.g. local cable TV } \\
\text { transmissions, web } \\
\text { camera, archived audio- } \\
\text { or videofiles) }\end{array}$ & 1 & $\overline{\mathrm{CB}}$ & & & & & & & & & & \\
\hline $\begin{array}{l}\text { better navigation for } \\
\text { searching responsible } \\
\text { civil servants }\end{array}$ & & & & & & & & & 1 & $\mathrm{JAB}$ & & \\
\hline $\begin{array}{l}\text { new instruments for } \\
\text { communication with } \\
\text { citizens / businesses in } \\
\text { administrative agendas } \\
\text { (e.g. skype, call centre, } \\
\text { SMS-/MMS-ing, } \\
\text { submission tracking, } \\
\text { Mobile Authority) }\end{array}$ & & & & & 2 & $\begin{array}{l}\mathrm{KOL}, \\
\mathrm{CH}\end{array}$ & 1 & PR10 & & & & \\
\hline $\begin{array}{l}\text { portal with tourist } \\
\text { information }\end{array}$ & & & & & & & 1 & JMK & & & & \\
\hline \multicolumn{13}{|l|}{$\begin{array}{l}\text { 2) Services designed } \\
\text { especially for internal use } \\
\text { in public admuinistration }\end{array}$} \\
\hline $\begin{array}{l}\text { digitalization of } \\
\text { documents, including the } \\
\text { GIS used only for internal } \\
\text { needs of public } \\
\text { authorities }\end{array}$ & & & 1 & $\mathrm{CH}$ & & & & & & & & \\
\hline $\begin{array}{l}\text { managerial and economic } \\
\text { information systems }\end{array}$ & & & 3 & $\begin{array}{l}\text { JAB, } \\
\text { KARK, } \\
\text { OLK }\end{array}$ & 2 & HL & 2 & $\begin{array}{l}\text { VYS, } \\
\text { ŠUM }\end{array}$ & 1 & PLZK & 2 & $\begin{array}{l}\text { ZLK, } \\
\text { VSE }\end{array}$ \\
\hline $\begin{array}{l}\text { - infrastructure of regional } \\
\text { communication network } \\
\text { within an administrative } \\
\text { territory of a municipality } \\
\text { / region (metropolitan } \\
\text { network) designed for } \\
\text { internal needs of public } \\
\text { administration (incl. data } \\
\text { depositories) }\end{array}$ & & & & & & VYS & & & & & & \\
\hline - portal of good practice & & & & NSZM & & & & & & & & \\
\hline
\end{tabular}


Table 1: continuous

\begin{tabular}{|c|c|c|c|c|c|c|c|c|c|c|c|c|}
\hline \multirow{2}{*}{$\begin{array}{l}\text { Types of awarded projects } \\
\text { according to the focus of their } \\
\text { services }\end{array}$} & \multicolumn{2}{|c|}{2005} & \multicolumn{2}{|c|}{2006} & \multicolumn{2}{|c|}{2007} & \multicolumn{2}{|c|}{2008} & \multicolumn{2}{|c|}{2009} & \multicolumn{2}{|c|}{2010} \\
\hline & No. & M/R & No. & $\mathbf{M} / \mathbf{R}$ & No. & M/R & No. & M/R & No. & M/R & No. & $\mathbf{M} / \mathbf{R}$ \\
\hline $\begin{array}{l}\text { 3) Services designed for the } \\
\text { public and for public } \\
\text { administration }\end{array}$ & & & & & & & & & & & & \\
\hline $\begin{array}{l}\text { - GIS related to territorial } \\
\text { planning which can be also used } \\
\text { by citizens }\end{array}$ & 1 & $\overline{D E \mathscr{E}}$ & & & & & & & & & & \\
\hline $\begin{array}{l}\text { selection of suppliers / public } \\
\text { procurement systems / system } \\
\text { for allocation of grants }\end{array}$ & & & & & & & 2 & $\begin{array}{l}\text { HOD, } \\
\text { STU }\end{array}$ & & & & \\
\hline $\begin{array}{l}\text { infrastructure of regional } \\
\text { communication network within a } \\
\text { metropolitan area which is } \\
\text { expanding into G2C / G2B } \\
\text { dimensions }\end{array}$ & & & & OST & & & & & & & & \\
\hline $\begin{array}{l}\text { projects offering communication } \\
\text { infrastructure in order to } \\
\text { standardize internal and external } \\
\text { processes (similarly to the } \\
\text { project Virtuos) }\end{array}$ & & & & & & & 1 & PLZK & & & & \\
\hline
\end{tabular}

Notes: $\mathrm{M}$ - municipality, $\mathrm{R}$ - region; $\mathrm{CH}=$ Chomutov, $\breve{\mathrm{C} B}=$ České Budějovice, DĚČ $=$ Děčín, KARK = Karlovarský kraj, OST = OSTRAVA, NSZM - Národní sít zdravých měst, OLK = Olomoucký kraj, JAB = Jablunkov, PřER = Přerov, KOL = Koleč, HL = Hlučín, VYS = Kraj Vysočina, ŠUM = Šumperk, STU = Studénka, PLZK = Plzeňský kraj, ZLK = Zlínský kraj, VSE = Vsetín.

Source: Author 
Table 2: Types of projects awarded in the Golden Crest competition in the period 2005 - 2010

\begin{tabular}{|c|c|c|c|c|c|c|c|c|c|c|c|c|}
\hline \multirow{2}{*}{$\begin{array}{l}\text { Types of awarded projects } \\
\text { according to the focus of } \\
\text { their services }\end{array}$} & \multicolumn{2}{|c|}{2005} & \multicolumn{2}{|c|}{2006} & \multicolumn{2}{|c|}{2007} & \multicolumn{2}{|c|}{2008} & \multicolumn{2}{|c|}{2009} & \multicolumn{2}{|c|}{2010} \\
\hline & No. & $\begin{array}{c}\mathbf{M} / \\
\mathbf{R}\end{array}$ & No. & $\mathbf{M} / \mathbf{R}$ & No. & $\mathbf{M} / \mathbf{R}$ & No. & $\mathbf{M} / \mathbf{R}$ & No. & $\begin{array}{c}\mathbf{M} / \\
\mathbf{R}\end{array}$ & No. & $\begin{array}{c}\mathbf{M} / \\
\mathbf{R}\end{array}$ \\
\hline $\begin{array}{l}\text { 1) Services designed } \\
\text { especially for public }\end{array}$ & & & & & & & & & & & & \\
\hline $\begin{array}{l}\text { electronic suppont of } \\
\text { service to customers } \\
\text { within premises of a } \\
\text { public authority (e.g. } \\
\text { terminals for credit card } \\
\text { payments, calling } \\
\text { systems) }\end{array}$ & 2 & $\begin{array}{l}\text { PRE, } \\
\text { VYSS }\end{array}$ & 2 & $\begin{array}{l}\text { BRNL, } \\
\text { Most }\end{array}$ & 1 & BRNL & & & & & & \\
\hline $\begin{array}{l}\text { increase of information } \\
\text { about activities of } \\
\text { political bodies } \\
\text { (municipal / regional } \\
\text { councils or boards) } \\
\text { (e.g. local cable TV } \\
\text { transmissions, web } \\
\text { camera, archived audio- } \\
\text { or videofiles) }\end{array}$ & & & 1 & $\mathrm{CB}$ & & & & & 1 & PRIB & & \\
\hline $\begin{array}{l}\text { new instruments for } \\
\text { communication with } \\
\text { citizens / businesses in } \\
\text { administrative agendas } \\
\text { (e.g. skype, call centre, } \\
\text { SMS-/MMS-ing, } \\
\text { submission tracking, } \\
\text { Mobile Authority) }\end{array}$ & & & & & 2 & $\begin{array}{l}\text { BRNL, } \\
\text { PR6 }\end{array}$ & 2 & $\begin{array}{l}\mathrm{BOH}, \\
\text { PR6 }\end{array}$ & 1 & SEM & & \\
\hline $\begin{array}{l}\text { portal with tourist } \\
\text { information }\end{array}$ & 1 & BER & & & & & & & & & & \\
\hline - e-museum & & & & & & & 1 & SEN & & & 1 & SEN \\
\hline $\begin{array}{l}\text { 3) Services designed for the } \\
\text { public and for public } \\
\text { administration }\end{array}$ & & & & & & & & & & & & \\
\hline $\begin{array}{l}\text { - GS related to territorial } \\
\text { planning which can be } \\
\text { also used by citizens }\end{array}$ & & & & & & & & & & & 1 & ŠUM \\
\hline $\begin{array}{l}\text { - selection of suppliers / } \\
\text { public procurement } \\
\text { systems / system for } \\
\text { allocation of grants }\end{array}$ & & & & & & & & & & & 1 & PR \\
\hline $\begin{array}{l}\text { infrastructure of regional } \\
\text { communication network } \\
\text { within a metropolitan } \\
\text { area which is expanding } \\
\text { into G2C / G2B } \\
\text { dimensions }\end{array}$ & & & & & 1 & OST & & & 1 & OST & & \\
\hline
\end{tabular}

Notes: $\mathrm{M}$ - municipality, R - region; BER = Beroun, PŘER = Přerov, VYŠ = Vyškov, BRNL = Brandýs nad Labem, $\breve{C B}=$ České Budějovice, OST = Ostrava, PR6 = Praha 6, PŘIB = Přibyslav, PR = Praha, ŠUM = Šmperk, SEN = Senorady.

Source: Author 
Table 3: Types of projects medialized within the competition of the magazine Egovernment.cz in the period 2005 - 2010*

\begin{tabular}{|c|c|c|c|c|c|c|c|c|}
\hline \multirow{2}{*}{$\begin{array}{l}\text { Types of awarded projects according to the focus of } \\
\text { their services }\end{array}$} & \multicolumn{2}{|c|}{2006} & \multicolumn{2}{|c|}{2007} & \multicolumn{2}{|c|}{2008} & \multicolumn{2}{|c|}{2010} \\
\hline & No. & $\mathbf{M} / \mathbf{R}$ & No. & M/R & No. & $\mathbf{M} / \mathbf{R}$ & No. & $\mathbf{M} / \mathbf{R}$ \\
\hline \multicolumn{9}{|l|}{ 1) Services designed especially for public } \\
\hline $\begin{array}{l}\text { - electronic support of service to customers within } \\
\text { premises of a public authority } \\
\text { (e.g. terminals for credit card payments, calling } \\
\text { systems) }\end{array}$ & 2 & $\begin{array}{l}\text { PŘER, } \\
\text { DĚČ }\end{array}$ & & & & & & \\
\hline - smart cards & 1 & PLZ & & & & & & \\
\hline - network of kiosks with (limited) free internet access & & & 1 & PR9 & 1 & PR1 & & \\
\hline $\begin{array}{l}\text { - free Wi-Fi Internet access through publicly financed } \\
\text { hotspots }\end{array}$ & 1 & PR5 & 1 & PR9 & & & & \\
\hline $\begin{array}{l}\text { increase of information about activities of political } \\
\text { bodies (municipal / regional councils or boards) } \\
\text { (e.g. local cable TV transmissions, web camera, } \\
\text { archived audio- or videofiles) }\end{array}$ & 1 & ČB & & & & & & \\
\hline $\begin{array}{l}\text { new instruments for communication with citizens / } \\
\text { businesses in administrative agendas (e.g. skype, } \\
\text { call centre, SMS-/MMS-ing, submission tracking, } \\
\text { Mobile Authority) }\end{array}$ & & & 1 & PR1 & 2 & $\begin{array}{l}\mathrm{CH}, \\
\text { PR1 }\end{array}$ & & \\
\hline - calendar of activities & & & & & & & & NYM \\
\hline - city portal (or a portal of a metropolitan area) & 1 & PR & & & & & & \\
\hline - portal with tourist information & & & & & & PLZK & & \\
\hline portal with information about environment & 1 & PR & & & 1 & & & \\
\hline \multicolumn{9}{|l|}{$\begin{array}{l}\text { 2) Services designed especially for internal use in } \\
\text { public administration }\end{array}$} \\
\hline $\begin{array}{l}\text { digitalization of documents, including the GIS used } \\
\text { only for internal needs of public authorities }\end{array}$ & & & 1 & ZLK & & & 2 & $\begin{array}{l}\text { DKNL, } \\
\text { LIT }\end{array}$ \\
\hline $\begin{array}{l}\text { - instruments for preparation of electronic materials } \\
\text { for political leadership and instruments facilitating } \\
\text { political decision-making (voting) }\end{array}$ & 1 & ČB & & UB & & & & \\
\hline - managerial and economic information systems & 1 & ZÁB & 2 & $\begin{array}{l}\text { PR, } \\
\text { PR1 }\end{array}$ & & & 2 & $\begin{array}{l}\text { PLZK, } \\
\text { KAR }\end{array}$ \\
\hline - file service systems & 1 & PR9 & & & 1 & BR & & \\
\hline $\begin{array}{l}\text { - infrastructure of regional communication network } \\
\text { within an administrative territory of a municipality / } \\
\text { region (metropolitan network) designed for internal } \\
\text { needs of public administration (incl. data } \\
\text { depositories) }\end{array}$ & 4 & $\begin{array}{l}\text { PLZ, } \\
\text { VYS, } \\
\text { PR, PEL }\end{array}$ & & & 1 & VYS & & \\
\hline - e-learning educational programmes & & & 1 & PR10 & & & & \\
\hline \multicolumn{9}{|l|}{$\begin{array}{l}\text { 3) Services designed for public as well as for public } \\
\text { administration }\end{array}$} \\
\hline $\begin{array}{l}\text { - GIS related to territorial planning which can be } \\
\text { used also by citizens }\end{array}$ & 2 & $\begin{array}{l}\text { HKK, } \\
\text { PLZ }\end{array}$ & & & & & 1 & ZLK \\
\hline $\begin{array}{l}\text { - selection of suppliers / public procurement systems } \\
\text { / system for allocation of grants }\end{array}$ & & & & & & & 1 & ZLK \\
\hline $\begin{array}{l}\text { - infrastructure of regional communication network } \\
\text { within a metropolitan area which is expanding into } \\
\text { G2C / G2B dimensions }\end{array}$ & 2 & $\begin{array}{l}\text { OST, } \\
\text { NVM }\end{array}$ & & & 1 & UB & & \\
\hline $\begin{array}{l}\text { projects offering communication infrastructure in } \\
\text { order to standardize internal and external processes } \\
\text { (similarly to the project Virtuos) }\end{array}$ & & & 1 & PLZK & 1 & PLZK & & \\
\hline - transport camera surveillance systems & & & 1 & OS & & & & \\
\hline - uniform school information system & & & 1 & PLZ & & & & \\
\hline
\end{tabular}

Notes: * Not only the three best finalists, but all The Best medialized projects are included in the table - see www.egovernment.cz; M - municipality, R - region; NVM = Nové Město na Moravě, PLZ = Plzeň, OST = Ostrava, P̌̌ER = Přerov, DĚČ = Děčín, ZÁB = Zábřeh, VYS = kraj Vysočina, PR1 = Městská část Praha 1 , PR5 = Městská část Praha 5, PR9 = Městská část Praha 9, PR10 = Městská část Praha 10, HKK = Královéhradecký kraj, PEL = Pelhřimov, ČB = České Budějovice, PLZK = Plzeňský kraj, UB = Uherský Brod, ZLK = Zlínský kraj, CH = Chomutov, BR = Brno, KAR = Karviná, DKNL = Dvůr Králové nad Labem LIT = Litomyšl, NYM = Nymburk.

Source: Author 
Table 4: Summary of focus of projects awarded in surveyed national e-government competitions in 2005 - 2010

\begin{tabular}{|c|c|c|}
\hline \multirow[t]{2}{*}{ Types of awarded projects (services) } & \multicolumn{2}{|c|}{$\begin{array}{l}\text { Number of } \\
\text { projects of }\end{array}$} \\
\hline & M & $\mathbf{R}$ \\
\hline 1) Services designed especially for public & 27 & 3 \\
\hline $\begin{array}{l}\text { - electronic support of service to customers within premises of a public authority (e.g. } \\
\text { terminals for credit card payments, calling systems) }\end{array}$ & 7 & \\
\hline - smart cards (Pilsencard) & 1 & \\
\hline - network of kiosks with (limited) free Internet access & 2 & \\
\hline - free Wi-Fi Internet access through publicly financed hotspots & 2 & \\
\hline $\begin{array}{l}\text { - increase of information about activities of political bodies (municipal / regional councils or } \\
\text { boards) } \\
\text { (e.g. local cable TV transmissions, web camera, archived audio-or videofiles) }\end{array}$ & 2 & \\
\hline - better navigation for searching civil servants & 1 & \\
\hline $\begin{array}{l}\text { - new instruments for communication with citizens / businesses in administrative agendas } \\
\text { (e.g. skype, call centre, SMS-/MMS-ing, submission tracking, Mobile Authority) }\end{array}$ & 8 & \\
\hline - calendar of activities & 1 & \\
\hline - city portal (or a portal of a metropolitan area) (Portal of Prague) & 1 & \\
\hline - portal with tourist information (e.g. Portal for cycloturism) & 1 & 2 \\
\hline - portal with information about environment (Prague's Atlas of Environment) & & 1 \\
\hline - e-museum (Senorady) & 1 & \\
\hline 2) Services designed especially for internal needs of public adninistration & 18 & 9 \\
\hline $\begin{array}{l}\text { - digitalization of documents, including the GIS used only for internal needs of public } \\
\text { authorities }\end{array}$ & 3 & 1 \\
\hline $\begin{array}{l}\text { - instruments for preparation of electronic materials for political leadership and instruments } \\
\text { facilitating political decision-making (voting) (e.g. c-City Council) }\end{array}$ & 2 & \\
\hline $\begin{array}{l}\text { - managerial and economic information systems } \\
\text { (e.g. portal of strategic management, system for monitoring of PC activities of employees, } \\
\text { dynamic BSC) }\end{array}$ & 7 & 6 \\
\hline - file service systems & 2 & \\
\hline $\begin{array}{l}\text { - infrastructure of regional communication network within an administrative territory of a } \\
\text { municipality / region (metropolitan network) designed for internal needs of public } \\
\text { administration (incl. data depositories) } \\
\text { (e.g. ROWANET, Pilsen metropolitan IS) }\end{array}$ & 2 & 2 \\
\hline - e-learning educational programmes (MP Prague 10) & 1 & \\
\hline - portal of good practice (e.g. Dataplan) & 1 & \\
\hline 3) Services designed for public as well as for public adnuinistration & 10 & 4 \\
\hline - GIS related to territorial planning which can be used also by citizens & 3 & 2 \\
\hline $\begin{array}{l}\text { - selection of suppliers / public procurement systems / allocation of grants } \\
\text { (e.g. Prague's portal Public Procurement Under the Eye-Loupe) }\end{array}$ & 2 & 1 \\
\hline $\begin{array}{l}\text { - infrastructure of regional communication network within a metropolitan area which is } \\
\text { expanding into } \mathrm{G} 2 \mathrm{C} / \mathrm{G} 2 \mathrm{~B} \text { dimensions } \\
\text { (e.g. eSMO?, iNovomésto, eObec) }\end{array}$ & 3 & \\
\hline $\begin{array}{l}\text { - projects offering communication infrastructure in order to standardize internal and external } \\
\text { processes (similarly to the project Virtuos) }\end{array}$ & & 1 \\
\hline - transport camera surveillance systems (Ostrava) & 1 & \\
\hline - uniform school information system (PilsEDUnet) & 1 & \\
\hline
\end{tabular}

Note: $\mathrm{M}$ - municipalities, $\mathrm{R}$ - Regions.

Source: Author 